\title{
Geoquímica de Terrenos Urbanos Modificados pela Humanidade e Serviços Ecossistêmicos (SE): o Caso de Santa Maria (RS, Brasil)
}

\author{
Humanly Modified Urban Ground Geochemistry and Ecosystem \\ Services (ES): the Case of Santa Maria (RS, Brazil)
}

\author{
Jéssica Rafaela da Costa ${ }^{1} \bowtie$ (iD), Alex Ubiratan Goossens Peloggia ${ }^{2} \bowtie$ \\ 1 Universidade de São Paulo, jrcosta@usp.br, \\ https://orcid.org/0000-0002-4636-2010 \\ 2Pesquisador independente, alexpeloggia@uol.com.br
}

\begin{abstract}
Resumo: As ações humanas deixam várias marcas no meio ambiente, o que inclui aquelas na camada geológica superficial do Planeta, incluindo a produção de terrenos tecnogênicos. Nas últimas décadas, a expansão urbana tem sido acompanhada por um crescimento de áreas degradadas, incluindo modificações no terreno pela introdução de materiais antropogênicos e ações como corte, revolvimento e compactação, que afetam as funções desses substratos ecológicos. No Brasil, este fenômeno tem se intensificado desde a segunda metade do século XX. Assim, o objetivo deste trabalho foi investigar as transformações nas propriedades das camadas superficiais da cidade de Santa Maria (RS), em termos geoquímicos, e como estas afetam os possíveis serviços ecossistêmicos proporcionados por essas camadas. Para tanto, foi realizada uma descrição morfológica dos perfis do terreno urbano e realizados ensaios laboratoriais para determinar: $\mathrm{pH}_{\mathrm{H} 2 \mathrm{O}}$, $\mathrm{pH}_{\mathrm{KCl}}, \mathrm{Ca}^{2}, \mathrm{Mg}^{2}, \mathrm{~K}, \mathrm{Na}, \mathrm{Al}^{3}, \mathrm{H}+\mathrm{Al}, \mathrm{Cu}, \mathrm{Zn}$ e cálculo de $\mathrm{S}, \mathrm{Al} \%$ e V\%. Os resultados apontaram que há uma enorme variação de constituintes antropogênicos no material capaz de alterar tanto as propriedades das camadas superficiais quanto suas funções e os serviços ecossistêmicos fornecidos.
\end{abstract}

Lavras-chave: Solo Urbano; Terrenos Tecnogênicos; Antropoceno.

Abstract: Human agency leaves several marks on the environment, which includes deep modifications on the geological surficial layers of the planet, including the formation of technogenic ground. In the last decades, urban expansion has been accompanied by an increase in the extension of degraded lands, which includes modifications in the ground by the introduction of anthropogenic materials and actions such as cutting, revolving and compaction, which affects ecosystem functions of these substrates. In Brazil, this process has intensified since the second half of the $20^{\text {th }}$ Century. Thus, the objective of this work was to investigate the changes in the ground geochemical properties of the city of Santa Maria (RS) and how it may affect the possible ecosystem services provided by these soils. For this purpose, a morphological description of soil profiles to identify the existence of anthropogenic layers was carried out and laboratory tests were conducted to determine $\mathrm{pH}_{\text {water }}, \mathrm{pH}_{\mathrm{KCl}}, \mathrm{Ca} 2, \mathrm{Mg} 2, \mathrm{~K}, \mathrm{Na}, \mathrm{Al3}, \mathrm{H}+\mathrm{Al}, \mathrm{Cu}, \mathrm{Zn}$ and calculation of $\mathrm{S}, \mathrm{Al} \%$ and $V \%$. The results pointed out that there is an enormous variation of anthropogenic constituents in the material, which are capable of altering both the properties of the ground surficial layers as well as their functions and the provided ecosystem services.

Keywords: Urban soil; Technogenic Ground; Anthropocene.

\section{Introduction}

The relationship between humankind and nature has been subject of diverse areas of knowledge, from Philosophy to Science and beyond. In recent decades it has also been realized that land use policies, both in urban and rural environments, need to encourage spatial planning practices not only from the economic point of view. Land use projects should also consider the ecological aspects of the environment, such as the provision of Ecosystem Services (ESs) by the most diverse actors in the environment (GREINERT et al., 2017). 
Ecosystem services can be defined as the conditions and processes through which natural and humanmodified ecosystems sustain and fulfil human life, encompassing tangible and intangible benefits (DAILY, 1997; MILLENIUM ECOSYSTEM ASSESSMENT, 2003). The use of the Ecosystem Service (ES) concept has become a constant in several studies to incorporate the idea of ecological sustainability in the decisionmaking for administrative policies (GRÊT-REGAMEY et al., 2015). In order for ESs to be fully achieved, it is imperative that supporting services provided by the physical environment are fulfilling their functions. Among these providers are soils and geological deposits, which are also created and modified by human agency, resulting in what has been named artificial or technogenic ground (WATERS, 2018; PELOGGIA, 2018).

Pedogenic soils and other surficial formations have several environmental functions, among which the Food and Agriculture Organization of the United Nations highlights: its role in carbon sequestration; in the water and contaminants purification; in climate regulation; in nutrient cycling; as habitat for organism; their role in regulating floods; soil as a source of energy and pharmaceutical resources; as the basis of human infrastructure; as a supplier of building materials; place of cultural heritage; and as an environment for the production of food, fuel and fiber.

From these functions, soil becomes a supplier of ESs that depend on the materials properties, which are often degraded not being able to properly develop their functions and, consequently, the supply of ESs. Despite their importance for environmental maintenance, soils and other surficial formations are under threat and suffering hard transformations worldwide. This situation stems from the fact that they are often marginalized in studies as a mere surface product of rock alteration (GREINER et al., 2017).

Considering that human welfare depends heavily on the resources provided by surficial layers as Soils Functions (SFs), including pedogenic and technogenic ones, it should be better integrated into ES assessments. Thus, Adhikari and Hartemink (2016) schematized the existing relationships between the "soil" (in a general sense) and human well-being in a diagram (Figure 1). According to the mentioned diagram, the properties of the soils are the basis for the understanding of how the soil develops certain functions, which reflect in ESs.

\begin{tabular}{|c|c|c|}
\hline Ecosystem Services & Soils functions & \multirow{8}{*}{$\begin{array}{c}\text { Soils Properties } \\
\text { Soil organic carbon } \\
\text { Silt, clay, sand \& Coarse fragments } \\
\text { Soil pH } \\
\text { Depth to bed rock } \\
\text { Bulk density } \\
\text { Available water capacity } \\
\text { Cation exchange capacity } \\
\text { Electrical conductivity } \\
\text { Soil porosity e air permeability } \\
\text { Hydraulic conductivity and infiltration } \\
\text { Soil biota } \\
\text { Soil structure \&aggregation } \\
\text { Soil temperature } \\
\text { Clay mineralogy } \\
\text { Subsoil pans }\end{array}$} \\
\hline Cultural; Supporting & Storing geological \& archeological heritage & \\
\hline Provision; Supporting & Biomass production & \\
\hline Regulation; Supporting & Storing, filtering \& transforming nutrients \& water & \\
\hline Supporting; Regulation; Provision & Hosting Biodiversity & \\
\hline Supporting & Platform for human activates & \\
\hline Provision & Source of raw material & \\
\hline Regulation; Supporting & Carbon pool & \\
\hline
\end{tabular}

Figure 1: Diagram of the Soil Property and Ecosystem Services (Source: adapted from ADHIKARI and HARTEMINK, 2016).

Considering research published between 1975 and 2014 linking soil properties and soil functions with ES, Adhikari and Hartemink (2016) revealed that about $41 \%$ of scientific articles relate soil to regulation services, $34 \%$ to provisioning, $8 \%$ to support cultural activities and infrastructure, and $13 \%$ to regulation. Despite the recognized multifunctional characteristic, the ground continues to be marginalised in studies about social welfare, especially in research conducted in urban centres. In order to minimize the process of urban ground degradation within cities, it is essential to consider the quality of these urban grounds in decision-making, considering their capacity to provide certain functions, which can guarantee their capacity to provide ES (DROBNIK et al., 2018).

Over the last few decades, urban population has intensively increased, which results with it vulnerability related upon ground characteristics, also associated with the environmental changes resulting from the way humankind appropriates the territory (MOREL et al., 2015). The anthropogenic (or technogenic) actions significantly alter the properties of urban ground, modifying functions performed by its layers and, consequently, the provision of ES. Among the properties of the urban ground layers, several of them are related to their chemical characteristics. Thus, the objective of this study was to investigate chemical 
indicators obtained from routine geochemical analyses, in order to understand how soil properties, in a city territory that in recent decades has presented a considerable expansion and population growth, and evaluate the ways in which this may be reflected upon SFs and ESs.

\section{Materials and Methods}

\subsection{Materials}

This study was developed in the municipality of Santa Maria, Rio Grande do Sul State, Southern Brazil (Figure 2). Its territory is under humid subtropical climate, with average annual temperature of $19^{\circ} \mathrm{C}$. Located in the central region of the State, Santa Maria is the $5^{\text {th }}$ largest city in the state in terms of population. According to the Brazilian Institute of Geography and Statistics (IBGE, 2010), the municipality has an estimated population of 270.000 inhabitants, which means a demographic density of 145 inhab / km².

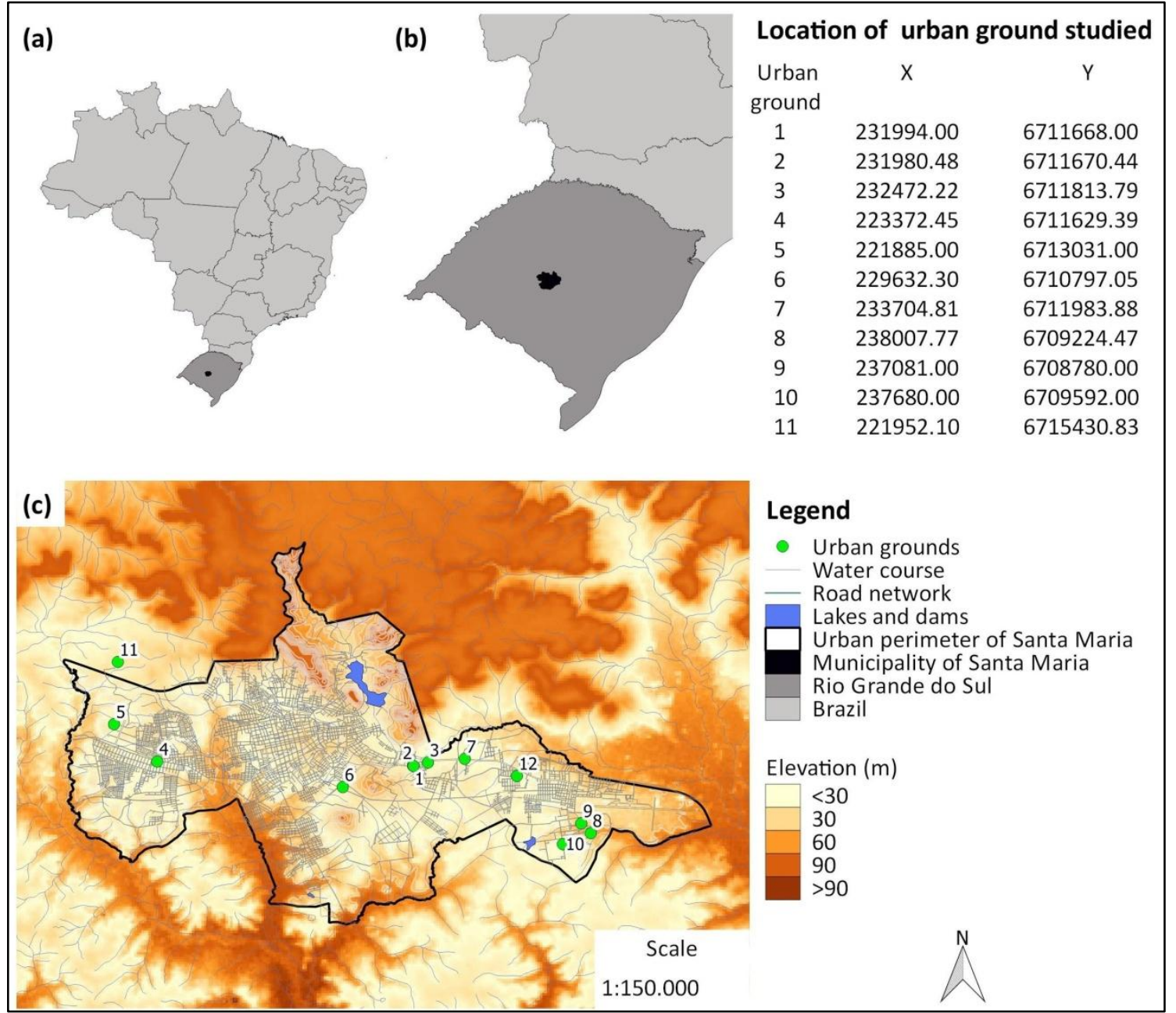

Figure 2: (a) Brazil; (b) Rio Grande do Sul; (c) Location of the urban ground studied.

\subsection{Methods}

Within the urbanized area of Santa Maria, twelve places were selected for ground profiles, with a depth of approximately $150 \mathrm{~cm}$. The profiles were chosen by the visual diversity observed in the field, by morphostratigraphic criteria, in order to express the urban ground variation in Santa Maria, that is, surficial layers geodiversity. The urban ground profiles were described morphologically in the field according Santos et al. (2015) to identify their layers and to collect samples for laboratory analysis.

The following properties was evaluated: potential acidity extracted with calcium acetate and titrated with sodium hydroxide; $\mathrm{pH}_{\text {water }}$ and $\mathrm{pH}_{\mathrm{KCl}}$; aluminum content in solution of potassium chloride and titration with sodium hydroxide, and the exchangeable calcium, magnesium, sodium, potassium, zinc and copper contents with flame photometer reading. By means of generated data were calculated values of total bases, base saturation and cation exchange capacity. All chemical tests were performed at the Laboratory of Pedology of the Federal University of Santa Maria according to the methods described in Teixeira et al. (2017). A descriptive statistical analysis was applied on the results to obtain a general view of the samples and the 
characteristics of the material, in order to relate the characteristics of the urban ground of Santa Maria with the diagram of Adhikari and Hartemink (2016).

\section{Results}

As clearly noted, Santa Maria is a predominantly artificial site, in terms of its surficial ground (Figure 3). The studied profiles show variability in the number of layers, as well as in the textures, structures and composition of the materials, characteristics has been described by Costa (2018). Among the morphological characteristics, variations of texture, thickness and quantity of technogenic layers were observed, besides the presence of several anthropogenic materials (artefacts or technofossils), mainly bricks, glass, metals, laminates and plastics.

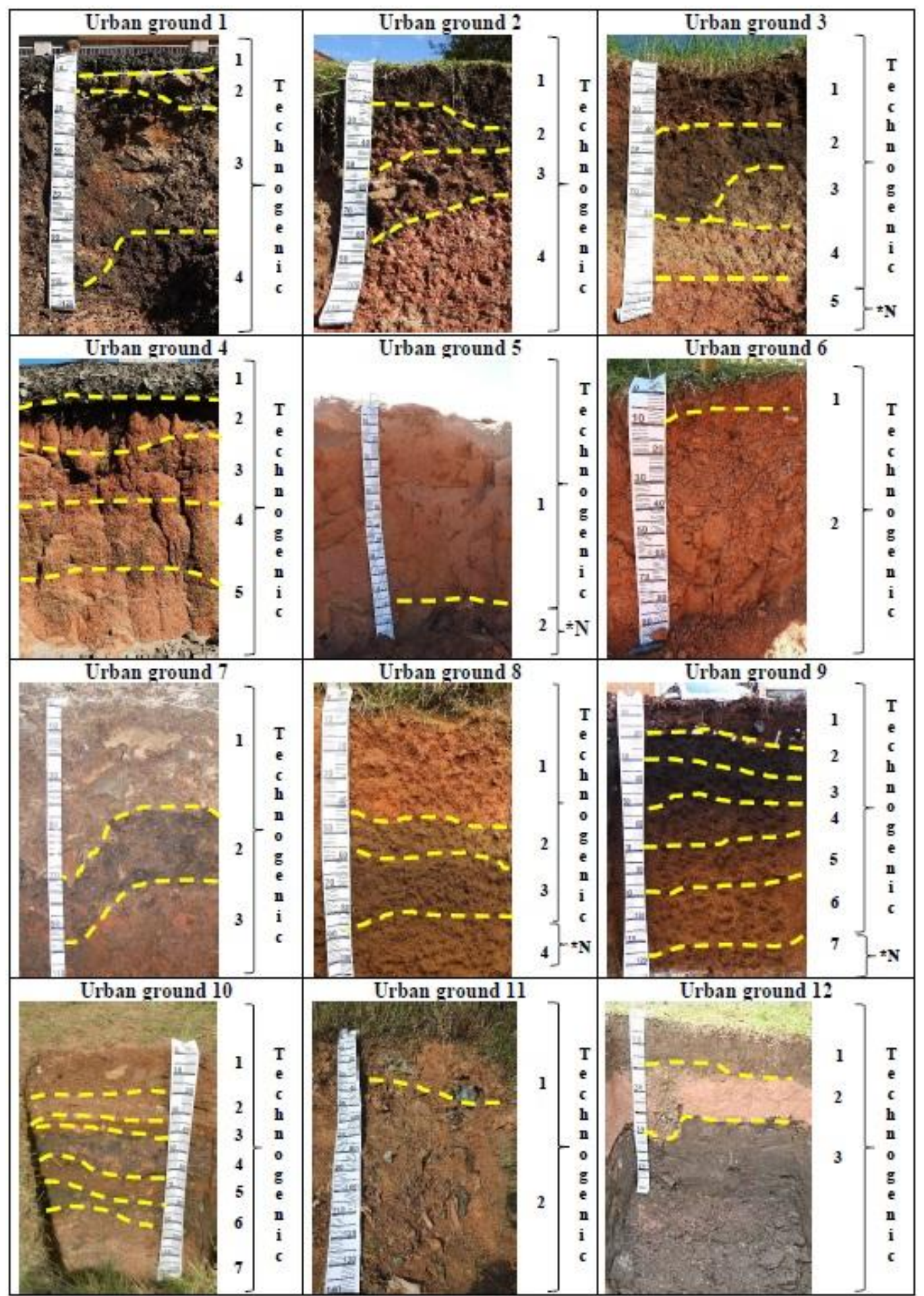

Figure 3: Studied urban ground profiles with indication of technogenic and natural layers. $* \mathrm{~N}$ : natural material (Source: adapted from COSTA, 2018) 
According to the chemical date, it is possible to observe that there is also heterogeneity in the samples collected. Table 1 shows the available data of the ground profiles, and Table 2 the results of the descriptive statistical analysis that summarizes the laboratory data. Table 3 shows, for comparison, the chemical standards for the regional soil.

Table 1. Chemistry analyses of the urban ground profiles.

\begin{tabular}{|c|c|c|c|c|c|c|c|c|c|c|c|c|c|c|c|}
\hline \multirow{2}{*}{ Profile } & \multirow{2}{*}{ Layers } & \multirow{2}{*}{$\begin{array}{c}\text { pH } \\
\mathrm{H}_{2} \mathrm{O}\end{array}$} & \multirow{2}{*}{$\begin{array}{c}\text { pH } \\
\text { KCl }\end{array}$} & \multicolumn{7}{|c|}{$\mathrm{cmol}_{\mathrm{c}} \mathrm{Kg}^{-1}$} & \multicolumn{2}{|c|}{$\mathrm{Mg} / \mathrm{Kg}^{-1}$} & \multirow{2}{*}{$\begin{array}{l}\text { CEC } \\
\text { pH } 7\end{array}$} & \multicolumn{2}{|c|}{$\%$} \\
\hline & & & & $\mathrm{Ca}^{2}$ & $\mathrm{Mg}^{2}$ & $\mathbf{K}$ & $\mathbf{N a}$ & $\mathbf{S}$ & $\mathrm{Al}^{3}$ & $\mathrm{H}+\mathrm{Al}$ & $\mathbf{C u}$ & Zn & & Al & $\mathbf{V}$ \\
\hline \multirow{4}{*}{1} & $1 \mathrm{~T}$ & - & - & - & - & - & & - & - & - & - & - & - & - & - \\
\hline & $2 \mathrm{~T}$ & 7.6 & 6.3 & 0.87 & 0.14 & 0.16 & 0.16 & 1.33 & 0.05 & 2.35 & 0.30 & 1.41 & 3.52 & 62.22 & 37.78 \\
\hline & $3 \mathrm{~T}$ & 5.3 & 3.9 & 2.17 & 0.31 & 0.18 & 0.23 & 2.89 & 1.65 & 22.65 & 0.21 & 0.35 & 25.31 & 88.59 & 11.41 \\
\hline & $4 \mathrm{~T}$ & 5.5 & 3.8 & 2.33 & 0.32 & 0.18 & 0.26 & 3.10 & 2.1 & 32.85 & 0.33 & 0.39 & 35.68 & 91.22 & 8.78 \\
\hline \multirow{4}{*}{2} & $1 \mathrm{~T}$ & - & - & - & - & - & & - & - & - & 0.54 & 6.84 & - & - & - \\
\hline & $2 \mathrm{~T}$ & 6.6 & 5.5 & 1.46 & 0.19 & 0.23 & 0.17 & 2.05 & 0.40 & 1.75 & 0.12 & 0.53 & 3.63 & 43.53 & 56.47 \\
\hline & $3 \mathrm{~T}$ & 5 & 5.4 & 3.93 & 0.46 & 0.22 & 0.19 & 4.79 & 0.30 & 3.75 & 2.40 & 1.16 & 8.36 & 42.71 & 57.29 \\
\hline & $4 \mathrm{~T}$ & 5.8 & 5.6 & 1.00 & 0.13 & 0.12 & 0.18 & 1.44 & 0.35 & 1.85 & 0.09 & 0.29 & 3.10 & 53.55 & 46.45 \\
\hline \multirow{5}{*}{3} & $1 \mathrm{~T}$ & 5.7 & 5.1 & 3.20 & 0.27 & 0.17 & 0.16 & 3.80 & 0.50 & 2.05 & 0.46 & 1.15 & 5.69 & 33.22 & 66.78 \\
\hline & $2 \mathrm{~T}$ & 6 & 4.6 & 1.41 & 0.16 & 0.09 & 0.16 & 1.83 & 1.20 & 2.45 & 0.27 & 0.35 & 4.11 & 55.48 & 44.52 \\
\hline & $3 \mathrm{~T}$ & 5.3 & 3.7 & 1.82 & 0.17 & 0.24 & 0.22 & 2.44 & 4.40 & 43.05 & 0.09 & 0.14 & 45.28 & 94.62 & 5.38 \\
\hline & $4 \mathrm{~T}$ & 5.6 & 3.9 & 3.52 & 0.33 & 0.15 & 0.23 & 4.23 & 1.25 & 23.25 & 0.07 & 0.32 & 27.25 & 84.48 & 15.52 \\
\hline & $5 \mathrm{~N}$ & 5.3 & 4.2 & 3.48 & 0.34 & 0.11 & 0.22 & 4.15 & 0.65 & 8.7 & 0.06 & 0.16 & 12.63 & 67.15 & 32.85 \\
\hline \multirow{5}{*}{4} & $1 \mathrm{~T}$ & 4.9 & 3.9 & - & - & - & - & - & - & - & - & - & - & - & - \\
\hline & $2 \mathrm{~T}$ & 4.7 & 3.5 & 0.60 & 0.08 & 0.12 & 0.18 & 0.97 & 0.05 & 1.85 & - & - & 2.65 & 63.4 & 36.6 \\
\hline & $3 \mathrm{~T}$ & 4.9 & 3.9 & 0.32 & 0.04 & 0.09 & 0.15 & 0.60 & 1.15 & 22.6 & 0.10 & 0.14 & 23.05 & 97.4 & 2.6 \\
\hline & $4 \mathrm{~T}$ & 4.4 & 3.9 & 0.07 & 0.07 & 0.09 & 0.16 & 0.39 & 0.85 & 16.75 & 0.17 & 0.26 & 16.98 & 97.72 & 2.28 \\
\hline & $5 \mathrm{~T}$ & 4.6 & 3.9 & 0.06 & 0.05 & 0.10 & 0.15 & 0.36 & 0.90 & 22.40 & 0.19 & 0.23 & 22.61 & 98.41 & 1.59 \\
\hline \multirow{2}{*}{5} & $1 \mathrm{~T}$ & 3.1 & 4.1 & 0.04 & 0.04 & 0.07 & 0.15 & 0.29 & 0.55 & 26.90 & 0.03 & 0.10 & 27.05 & 89.28 & 10.72 \\
\hline & $2 \mathrm{~N}$ & 3.2 & 4.1 & 0.01 & 0.03 & 0.07 & 0.15 & 0.26 & 0.30 & 14.00 & 0.02 & 0.15 & 14.11 & 81.58 & 18.42 \\
\hline \multirow{2}{*}{6} & $1 \mathrm{~T}$ & 7.0 & 6.4 & 1.69 & 0.07 & 0.29 & 0.19 & 2.23 & 0.15 & 1.80 & 0.12 & 3.39 & 3.85 & 42.08 & 57.92 \\
\hline & $2 \mathrm{~T}$ & 8.5 & 7.1 & 3.97 & 0.36 & 0.28 & 0.25 & 4.85 & 0.13 & 1.80 & 0.05 & 0.37 & 6.41 & 24.34 & 75.66 \\
\hline \multirow{3}{*}{7} & $1 \mathrm{~T}$ & 5.6 & 4.0 & 0.84 & 0.63 & 0.26 & 0.49 & 2.22 & 0.25 & 22.85 & 0.27 & 0.58 & 24.58 & - & - \\
\hline & $2 \mathrm{~T}$ & 4.9 & 3.7 & 0.30 & 0.25 & 0.24 & 0.46 & 1.25 & 1.85 & 49.00 & 0.30 & 0.74 & 49.79 & 90.97 & 9.03 \\
\hline & $3 \mathrm{~T}$ & 5.3 & 3.9 & 0.75 & 0.46 & 0.24 & 0.48 & 1.93 & 1.65 & 22.75 & 0.31 & 0.59 & 24.20 & 97.49 & 2.51 \\
\hline \multirow{5}{*}{8} & $1 \mathrm{~T}$ & 5.0 & 4.0 & 0.13 & 0.07 & 0.09 & 0.16 & 0.45 & 1.55 & 1.55 & 0.17 & 0.27 & 1.84 & 75.55 & 24.45 \\
\hline & $2 \mathrm{~T}$ & 5.0 & 4.0 & 0.04 & 0.06 & 0.07 & 0.15 & 0.33 & 1.20 & 1.65 & 0.16 & 0.23 & 1.82 & 81.87 & 18.13 \\
\hline & $3 \mathrm{~T}$ & 5.0 & 3.9 & 0.04 & 0.03 & 0.08 & 0.16 & 0.31 & 1.80 & 17.70 & 0.18 & 0.25 & 17.85 & 98.27 & 1.73 \\
\hline & $4 \mathrm{~N}$ & 4.8 & 3.9 & 0.04 & 0.03 & 0.07 & 0.16 & 0.31 & 1.75 & 17.40 & 0.17 & 0.12 & 14.54 & 97.87 & 2.13 \\
\hline & $5 \mathrm{~N}$ & 4.7 & 3.8 & 0.04 & 0.04 & 0.08 & 0.17 & 0.33 & 2.50 & 31.45 & 0.17 & 0.13 & 31.61 & 98.96 & 1.04 \\
\hline & $1 \mathrm{~T}$ & 6.3 & 6.5 & 1.95 & 0.13 & 0.63 & 0.49 & 3.19 & 0.50 & 40.20 & 0.74 & 21.83 & 42.91 & 92.57 & 7.43 \\
\hline & $2 \mathrm{~T}$ & 6.3 & 6.2 & 1.37 & 0.12 & 0.48 & 0.46 & 2.43 & 0.20 & 50.60 & 0.15 & 2.04 & 52.57 & 95.38 & 4.62 \\
\hline & $3 \mathrm{~T}$ & 5.0 & 4.3 & 0.75 & 0.16 & 0.36 & 0.45 & 1.73 & 1.55 & 1.05 & 0.17 & 0.32 & 2.32 & 25.44 & 74.56 \\
\hline 9 & $4 \mathrm{~T}$ & 4.3 & 4.0 & 0.42 & 0.18 & 0.31 & 0.45 & 1.36 & 2.05 & 1.85 & 0.17 & 0.29 & 2.76 & 50.73 & 49.27 \\
\hline & $5 \mathrm{~T}$ & 4.4 & 3.9 & 0.34 & 0.13 & 0.24 & 0.42 & 1.12 & 2.10 & 10.25 & 0.12 & 0.24 & 10.96 & 89.79 & 10.21 \\
\hline & $6 \mathrm{~T}$ & 4.4 & 4.0 & 0.24 & 0.12 & 0.22 & 0.45 & 1.03 & 2.10 & 31.75 & 0.08 & 0.19 & 32.33 & 96.82 & 3.18 \\
\hline & $7 \mathrm{~N}$ & 4.2 & 3.9 & 0.09 & 0.10 & 0.23 & 0.45 & 0.87 & 2.20 & 41.50 & 0.07 & 0.19 & 41.92 & 97.93 & 2.07 \\
\hline & $1 \mathrm{~T}$ & 5.3 & 4.0 & 0.91 & 0.18 & 0.24 & 0.46 & 1.80 & 1.25 & 39.95 & 0.21 & 0.17 & 41.28 & 95.64 & 4.36 \\
\hline & $2 \mathrm{~T}$ & 5.3 & 3.8 & 0.73 & 0.17 & 0.22 & 0.45 & 1.56 & 1.05 & 49.55 & 0.19 & 0.27 & 50.67 & 96.93 & 3.07 \\
\hline & $3 \mathrm{~T}$ & 5.2 & 3.8 & 4.04 & 0.57 & 0.23 & 0.46 & 5.29 & 2.15 & 14.60 & 0.29 & 0.26 & 19.44 & 72.79 & 27.21 \\
\hline 10 & $4 \mathrm{~T}$ & 7.8 & 7.3 & 1.16 & 0.18 & 0.23 & 0.45 & 2.02 & 0.15 & 24.05 & 0.67 & 0.83 & 25.62 & 92.12 & 7.88 \\
\hline & $5 \mathrm{~T}$ & 7.1 & 6.8 & 2.52 & 0.31 & 0.26 & 0.45 & 3.53 & 0.15 & 41.65 & 0.55 & 1.74 & 44.74 & 92.11 & 7.89 \\
\hline & $6 \mathrm{~T}$ & 4.3 & 3.8 & 0.27 & 0.18 & 0.21 & 0.43 & 1.09 & 1.55 & 53.63 & 0.28 & 0.16 & 54.29 & 98.0 & 2.00 \\
\hline & $7 \mathrm{~T}$ & 4.8 & 3.6 & 4.00 & 0.50 & 0.27 & 0.46 & 5.23 & 0.25 & 2.05 & 0.23 & 0.27 & 6.82 & 23.32 & 76.68 \\
\hline & $1 \mathrm{~T}$ & 5.9 & 4.9 & 0.58 & 0.18 & 0.51 & 0.43 & 1.69 & 0.65 & 50.30 & 0.58 & 2.43 & 51.57 & 96.73 & 3.27 \\
\hline 11 & $2 \mathrm{~T}$ & 5.6 & 5.4 & 0.66 & 0.17 & 0.54 & 0.46 & 1.83 & 0.55 & 44.75 & 0.51 & 4.46 & 46.12 & 96.04 & 3.96 \\
\hline & $1 \mathrm{~T}$ & 5.5 & 4.3 & 0.26 & 0.24 & 0.24 & 0.42 & 1.16 & 0.60 & 6.45 & 0.17 & 0.62 & 7.19 & 83.87 & 16.13 \\
\hline 12 & $2 \mathrm{~T}$ & 7.6 & 6.5 & 0.17 & 0.10 & 0.20 & 0.41 & 0.88 & 0.10 & 0.75 & 0.03 & 0.12 & 1.22 & 27.87 & 72.13 \\
\hline & $3 \mathrm{~T}$ & 6.3 & 5.2 & 0.44 & 0.22 & 0.24 & 0.44 & 1.34 & 0.40 & 51.20 & 0.31 & 0.70 & 52.1 & 97.43 & 2.57 \\
\hline
\end{tabular}

T: technogenic layer. N: natural layer.

In Table 1 is noticeable the absence of data for some layers, this is due to the impossibility collecting sufficient sample as a consequence of the existence of a hardened layer as a consequence a hardened layer. 
Table 2: Descriptive statistical analysis

\begin{tabular}{lccccc}
\hline \multicolumn{1}{c}{ Properties } & Average & Minimum & Maximum & $\begin{array}{c}\text { Standard } \\
\text { deviation }\end{array}$ & Coefficient of variation \\
\hline $\mathbf{H + A l}^{\mathbf{3}}$ (cmolc kg-1) & 21.15 & 0.75 & 53.63 & 17.91 & 84.68 \\
$\mathbf{C a}^{2}$ (cmolc kg-1) & 1.2 & 0.01 & 4.04 & 1.28 & 106.66 \\
Mg$^{2}$ (cmolc kg-1) & 0.2 & 0.03 & 0.63 & 0.15 & 75 \\
Na (cmolc kg-1) & 0.31 & 0.15 & 0.49 & 0.139 & 44.83 \\
K (cmolc kg-1) & 0.22 & 0.07 & 0.63 & 0.13 & 59.09 \\
Cu (mg kg-1) & 0.27 & 0.02 & 2.4 & 0.365 & 135.18 \\
Zn (mg kg-1) & 1.13 & 0.1 & 21.83 & 3.28 & 290.26 \\
Al (cmolc kg-1) & 1.07 & 0.05 & 4.4 & 0.89 & 83.17 \\
S (cmolc kg-1) & 1.92 & 0.26 & 5.29 & 1.43 & 74.47 \\
CEC & 22.7 & 1.22 & 54.29 & 17.79 & 78.37 \\
V \% & 22.49 & 1.04 & 76.68 & 24.59 & 109.33 \\
Al \% & 77.51 & 23.32 & 98.96 & 24.59 & 31.72 \\
pHwater & 5.42 & 3.1 & 8.5 & 1.11 & 20.47 \\
pHKCl & 4.6 & 3.5 & 7.3 & 1.08 & 23.47 \\
\hline & & & & & \\
\hline
\end{tabular}

Table 3: Chemical data of the modal profile of the Santa Maria Mapping Unit ("Unidade de Mapeamento Santa Maria") (Source: BRASIL, 1973).

\begin{tabular}{|c|c|c|c|c|c|c|}
\hline \multicolumn{2}{|c|}{ Horizon } & A1 & A2 & $\mathbf{A B}$ & Bt & C \\
\hline \multicolumn{2}{|c|}{ Depth } & $0-20$ & $20-40$ & $40-55$ & $55-75$ & $75-115$ \\
\hline \multicolumn{2}{|c|}{ pH $\mathrm{H}_{2} \mathrm{O}$} & 4.9 & 5.3 & 5.3 & 5.7 & 6.3 \\
\hline \multirow[t]{3}{*}{ pH } & KCl & 3.8 & 3.9 & 3.8 & 4 & 4.4 \\
\hline & $\mathrm{Ca}^{2}$ & 3.4 & 2.8 & 4.3 & 12.7 & 17.4 \\
\hline & $\mathbf{M g}^{2}$ & 0.8 & 0.5 & 0.6 & 1.5 & 2.2 \\
\hline \multirow{5}{*}{$\underset{\mathbf{K g}^{-1}}{\mathbf{c m o l}_{\mathbf{c}}}$} & $\mathbf{K}$ & 0.1 & 0.06 & 0.06 & 0.07 & 0.08 \\
\hline & $\mathbf{N a}$ & 0.06 & 0.06 & 0.11 & 0.25 & 0.35 \\
\hline & $\mathbf{S}$ & 4.3 & 2.9 & 5.1 & 14.6 & 20 \\
\hline & $\mathbf{A l}^{3}$ & 2.2 & 3.2 & 6.2 & 4.9 & 0.4 \\
\hline & $\mathbf{H}+\mathbf{A l}$ & 7.8 & 8.6 & 10 & 7.3 & 1.2 \\
\hline \multirow{2}{*}{$\mathbf{M g} / \mathbf{K g}^{-}$} & $\mathbf{C u}$ & - & - & - & - & - \\
\hline & $\mathbf{Z n}$ & - & - & - & - & - \\
\hline CEC & pH 7 & 12.1 & 11.96 & 14.96 & 21.57 & 20.88 \\
\hline \multirow{2}{*}{$\%$} & $\mathbf{A l}$ & 0.28 & 0.37 & 0.61 & 0.64 & 0.003 \\
\hline & $\mathbf{V}$ & 35 & 26 & 34 & 55 & 94 \\
\hline
\end{tabular}

It is evident that the urban strata of Santa Maria have low values of alkaline earth bases, irregularly distributed in the layers, and relatively high values of alkaline bases in general, as well as relatively low levels of $\mathrm{S}$ and $\mathrm{Al}$, variations that can occur in the same profile. 
The results also showed that the coefficient of variation is high for all properties. However, zinc had a higher coefficient of variation $(290 \%)$, indicating that there is no trend of values. The $\mathrm{pH}_{\text {water }}$ varied between 3.1 (profile 5, layer 1) and 8.5 (profile 6, layer 2), but the coefficient of variation found was the lowest among the considered properties, of about $20 \%$, which means that among the analyzes performed. The values of $\mathrm{pH}_{\text {water }}$ are the most well standardized, that is, the mean of 5.42 expresses the $\mathrm{pH}$ trend of the Santa Maria urban ground.

The values of potential acidity showed a great variation with minimum of 0.75 (profile 12, layer 2) and maximum of $53.63 \%$ (profile 12, layer 2), which was influenced by the values of exchangeable aluminium, which in turn is possibly related to the presence of anthropogenic materials present in the urban ground. Considering Adhikari and Hartemink diagram (2016), it is seen that the chemical properties variations of the urban ground affect, directly or indirectly, at least six of the seven functions performed by the soils and cited by the authors (production of biomass; stock, and filter of nutrients and water; biological reserve; support for human activities; carbon stock; source of raw material). Since soil functions are affected by human actions, all ES groups are vulnerable to modifications. Thus, for the urban ground of Santa Maria, it is possible to present an adaptation of the diagram of Adhikari and Hartemink (2016) presenting the relation properties of soils and ES (Figure 4).

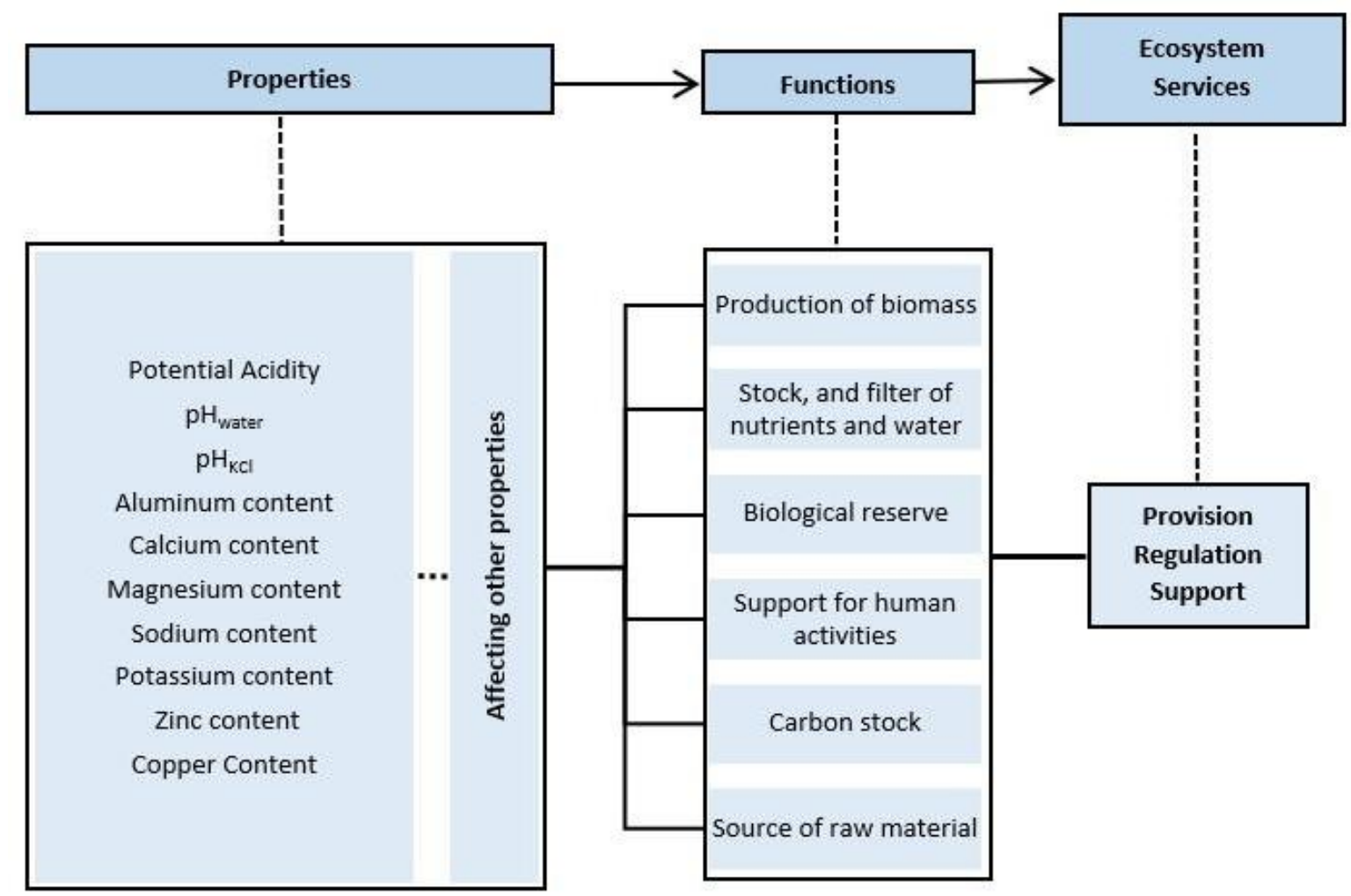

Figure 3: Relationship between chemical properties and Ecosystem Services (Source: Authors)

\section{Discussions}

The urban ground in Santa Maria, showed surficial technogenic characteristics, referred as the urban geological stratum (ZALASIEWICZ, 2008), which is part of the human modified ground, or archaeosphere (EDGEWORTH, 2017). The analysed profiles, as a consequence of the addition of anthropogenic materials in the environment, show highly varied chemical characteristics, as found in several other studies (SÉRÉ et al., 2010; SHARMA, 2015; GORBOV, 2016), reinforcing the perception of the compositional heterogeneity of urban ground. Although not all the soil properties presented in the diagram of Adhikari and Hartemink (2016) have been used, it is seen that the chemical properties selected and belonging to the group of "routine soil analysis" are able to indicate alterations that are occurring on other properties. Highly discrepant minimum and maximum values show that urban ground does not maintain a homogeneous environment along the profiles. This situation causes the potential soil functions to be changed along the profile, which consequently affects the ES of the site.

Anthropogenic (technogenic) materials present in the earthy mass of urban ground layers influence the chemical characteristics of urban soils (Morel and De Kimpe 1998) and deposits. The chemical analysis of calcium, magnesium, aluminium, potential acidity, sodium, potassium, copper, and zinc showed how 
these elements present varying concentrations according to the presence of technogenic residues. The copper content indicated relatively low values $\left(<0.8 \mathrm{mg} \mathrm{kg}^{-1}\right)$, but there was the exception of layer 3 of profile 2 where the value was much higher than the other urban ground sampled $\left(2.4 \mathrm{mg} \mathrm{kg}^{-1}\right)$. This value can be explained by the proximity of high traffic roads, as suggested by Gaberšek and Gosar (2018).

The analysis of profile 9 indicated in layer 1 value $21.83 \mathrm{mg} \mathrm{kg}^{-1}$ of zinc, while in the other urban ground samples, the predominant values were below $0.9 \mathrm{mg} \mathrm{kg}^{-1}$. In studies on urban ground (EL KHALIL et al., 2008; GALITSKOVA and MURZAYEVA, 2016; FOTI et al., 2017), as in the presented study, higher values of zinc were found in garbage disposal environments. For Mamedes (2017) the presence of zinc in the urban ground is mainly associated with the presence of metallic alloys, paints, and papers. According to Madrid et al. (2002), zinc, copper and lead are the most common inorganic pollutants in urban soil, and their association with organic matter and calcium carbonate alters their mobility in the soil (OLIVARES RIEUMONT, 2013).

According to Waterlot et al. (2016) another analysis affected by the anthropogenic materials is the soil $\mathrm{pH}$. The values of $\mathrm{pH}_{\text {water }}$ ranged from 3.1 to 8.5 (Table 1), with a higher frequency of 5.3 values for $\mathrm{pH}_{\text {water }}$ and 3.8 for $\mathrm{pH}_{\mathrm{KCl}}$. The profile 10, has in its third layer $(36-64 \mathrm{~cm})$ a value of $5.2 \mathrm{for}_{\mathrm{pH}}$ water, while in the subsequent one $(64-77 \mathrm{~cm})$, composed of a mixture of material that includes bricks and ceramics, the $\mathrm{pH}$ is of 7.8 .

The results of $\mathrm{pH}$ were different from the averages between 7 and 8 pointed out by Puskás and Farsang (2009) as common for urban ground that has received deposition of building material rich in carbonates. This difference can be due to the amount of construction debris in the urban ground (LASSO et al., 2013). Another explanation is the time of deposition of the materials. In young depositions, anthropogenic residues and the earthy material of the urban layers may not interact sufficiently for significant chemical changes (WISEMAN et al., 2015).

According to Brady and Weill (2015), the pH change of soils alters its flocculation capacity, which in turn influences in the formation and stabilization of aggregates and structures, important physical aspects of the water and gas dynamics from soil. The type of soil structure is fundamental for certain ESs since good structures facilitate the hydraulic and gas conductivity (BASSO and KIANG, 2017). Environments with high values of potential acidity tend to have the modified buffering power, which also affects the formation of aggregates.

The values of $\mathrm{Ca}, \mathrm{Mg}, \mathrm{Na}, \mathrm{K}$ and $\mathrm{Al}$ indicate the need to be considered such elements when planning to change land use, since these elements are fundamental for plant nutrition, for example. To use the soils as green environments, such as squares, parks, and gardens, it is fundamental to consider the great variety of these elements within the profiles, once the presence of these elements in the soil affects the production of biomass. Thus, in order for soils to be able to exercise ES, it is essential to consider these elements not only in the surface layers but also in the underlying ones, since the urban ground is an open system, where the liquid and gaseous phases are in constant connection.

\section{Conclusions}

The urban ground of Santa Maria is a clear example of the heterogeneity and complexity of the urban geological stratum or humanly modified ground. Therefore, it is expected that the geochemical properties of the natural and overlying technogenic layers may affect several functions reflected in the ES in much different ways, but still it is necessary to advance in studies that indicate the diversity of existent ES are affected by the characteristics of the modified soils.

It is also clear from this study that for urban ground modified, the usual standards considered for natural soils cannot be expected or applied. In this case, the evaluation of ESs must consider chemical properties of the layers according to their origin and constituent material.

Thus, since it has been shown that the provision of ecosystem services related to the urban ground is a function of the technogenic geodiversity (sensu PELOGGIA et al., 2014), it is understood that the mapping of artificial ground and of the urban geological stratum should come to be a priority when it comes to thinking about planning actions in the "cities of the Anthropocene." 


\section{References}

ADHIKARI K.; HARTEMINK A. E. Linking soils to ecosystem services - A global review. Geoderma, v.262, 101-111. 2016. DOI:10.1016/j.geoderma.2015.08.009.

BASSO J. B.; KIANG, C. H. Retardamento e dispersão hidrodinâmica de cobre, potássio e cloreto em solos residuais do subgrupo Itararé no estado de São Paulo. Águas Subterrâneas, v.31, 117-133. 2017. DOI:10.14295/ras.v31i1.28638.

BRADY N. C.; WEIL R. R. The nature and properties of soil. 13th edition, New Jersey: Prentice-Hall, 960p. 2015.

BRASIL. Ministério de Agricultura. Levantamento de reconhecimento dos solos do Estado do Rio Grande do Sul. Recife. 1973.

COSTA, J. R. Procedimento para análise de campo e identificação de qualificadores diagnósticos para solos urbanos. Mestrado. Universidade Federal de Santa Maria, 2018, 93p.

DAYLY, G. C. Introduction: What are ecosystem services? In: Dayly, G.C. (eds) Nature's Services: Social Dependence on Natural Ecosystems. Washington, Island Press, 1-10p. 1997.

DROBNIK T.; GREINERB L.; KELLERB A.; GRÊT-REGAMEYA, A. Soil quality indicators - From soil functions to ecosystem services. Ecological Indicators, v.94, 151-169. 2018. DOI:10.1016/j.ecolind.2018.06.052.

EDGEWORTH M. Humanly modified ground. In: Della-Sala D.A., Goldstein M.I. (eds) The Encyclopaedia of the Anthropocene. Elsevier, Oxford, 157-161p. 2017.

EL KHALIL H.; EL HAMIANI O.; BITTON G.; OUAZZANI N.; BOULARBAH A. Heavy metal contamination from mining sites in South Morocco: monitoring metal content and toxicity of soil runoff and groundwater. Environ. Monit. Assess., v.136, 147-160. 2008. DOI:10.1007/s10661-007-9671-9.

FOTI L., DUBS F., GIGNOUX J., LATA J. C., LERCH T. Z., MATHIEU J., NOLD F., NUNAN N., RAYNAUD X., ABBADIE L., BAROT S. Trace element concentrations along a gradient of urban pressure in forest and lawn soils of the Paris region (France). Sci Total Environ., v.598, 938-948. 2017. DOI:10.1016/j.scitotenv.2017.04.111.

GABERŠEK M.; GOSAR M. Geochemistry of urban soil in the industrial town of Maribor, Slovenia. Journal of Geochemical Exploration. v.187, 141-154. 2018. DOI:10.1016/j.gexplo.2017.06.001

GALITSKOVA Y. M.; MURZAYEVA A. I. Urban soil contamination. Procedia Engineering., v.153, 162166. 2016. DOI:10.1016/j.proeng.2016.08.097.

GORBOV S. N.; BEZUGLOVA O. S.; ABROSIMOV K. N.; SKVORTSOVA E. B.; TAGIVERDIEV S. S.; MOROZOV I. V. Physical Properties of Soils in Rostov Agglomeration. Eurasian Soil Science, v.49, 898907. 2016. DOI:10.1134/S106422931606003X.

GREINERT A. The heterogeneity of urban soils in the light of their properties. Journal of Soils and Sediments, v.15, 1725-1737. 2015. DOI:10.1007/s11368-014-1054-6..

GRÊT-REGAMEY A.; WEIBEL B.; KIENAST F.; RABE S.; ZULIAN G. A tiered approach for mapping ecosystem services. Ecosystem Services, v.13, 16-27. 2015. DOI:10.1016/j.ecoser.2014.10.008

IBGE - Instituto Brasileiro de Geografia e Estatística. Censo Demográfico 2010. Disponível em: <https://censo2010.ibge.gov.br/>. Acessado em 30 de outubro de 2018.

LASSO P. R. O.; VAZ C. M. P.; BERNARDI A. C. C.; OLIVEIRA C. R.; BACCHI O. O. S. Avaliação do uso de resíduos de construção e demolição reciclados como corretivo da acidez do solo. Rev. Bras. Ciênc. Solo, v.37, 1659-1668. 2013. DOI:10.1590/S0100-06832013000600022 .

MADRID L.; DÍAZ-BARRIENTOS E.; MADRID F. Distributions of heavy metals contents of urban soils in parks of Seville. Chemosphere, v.49, 1301-1308. 2002. DOI:10.1016/S0045-6535(02)00530-1.

MAMEDES I. M. Influência da disposição inadequada de resíduos sólidos urbanos sobre o solo: Estudo de caso do lixão de Várzea Grande-MT. R. gest. sust. ambient.,Florianópolis, v.5, 327-336. 2017.

MILLENIUM ECOSYSTEM ASSESSMENT. 2003. Ecosystems and human well-being: aa framework for assessment. Whashington, Island Press, 245p. 
MOREL J. L.; DE KIMPE C. 1998. Urban and sub-urban soils: a new playground for soil scientists. In: World CongressofSoil Science, Montpellier.

MOREL J. L.; CHENU C.; LORENZ K. Ecosystem services provided by soils of urban, industrial, traffic, mining, and military areas (SUITMAs). J Soils Sediments, v.15, 1659-1666. 2015. DOI:10.1007/s11368014-0926-0.

OLIVARES RIEUMONT S.; GARCÍA CÉSPEDES D.; LIMA CAZORLA L.; SABORIT SÁNCHEZ I.; LLIZOCASALS A.; PÉREZ ÁLVARES P. Niveles de cadmio, plomo, cobre y zincenhortalizas cultivadas en una zona altamente urbanizada de laciudad de la Habana, Cuba. Rev. Int. Contam. Ambie., v.29, 285294. 2013. ISSN 0188-4999.

PElogGiA A. U. G.; OliveIRA A. M. S.; OliVEIRA A. A.; SILVA E. C. N.; NUNES J. O. R. Technogenic geodiversity: a proposal on the classification of artificial ground. Quaternary and Environmental Geosciences, v.5, n.1, 28-40. 2014. DOI:10.5380/abequa.v5i1.34823.

PELOGGIA, A. U. G. Geological classification and mapping of technogenic (artificial) ground: a comparative analysis. Revista do Instituto Geológico, v.39, n.2, 1-15, 2018. DOI: 10.5935/0100929X.20180005.

PUSKÁS I.; FARSANG A. Diagnostic indicators for characterizing urban soil of Szeged, Hungary. Geoderma, v.148, 267-281. 2009. DOI:10.1016/j.geoderma.2008.10.014

SANTOS, R. D.; LEMOS, R. C.; SANTOS, H. G.; KER, J. C.; ANJOS, L. H. C.; SHIMIZU, S. H. Manual de descrição e coleta de solo no campo. 7th edition, Viçosa: Sociedade Brasileira de Ciência do Solo, 170p. 2015.

SÉRÉ G.; SCHWARTZ C.; OUVRARD S.; RENAT J.C.; WATTEAU F.; VILLEMIN G. MOREL J. L. Early pedogenic evolution of constructed Technosols. J Soils Sediments, v.10, 1246-1254. 2010. DOI:10.1007/s11368-010-0206-6.

SHARMA N. K. From natural to human-impacted ecosystems: rationale to investigate the impact of urbanization on cyanobacterial diversity in soils. BiodiversConserv., v.24, 1007-1015. 2015. DOI:10.1007/s10531-015-0897-5.

TEIXEIRA P. C.; DONAGEMMA G. K.; FONTANA A.; TEIXEIRA, W.G. (eds). Manual de métodos de análisis de solos. 3. ed. Brasília: Embrapa, 573p. 2017.

WATERLOT C., PELFRÊNE A., DOUAY F. Determining the influence of the physicochemical parameters of urban soils on as availability using chemometric methods: A preliminary study. J. Environ. Sci., v.47, 183-192. 2016. DOI:10.1016/j.jes.2015.12.028.

WATERS, C. N. Artificial ground. In: P.T. Bobrowsky, B. Marker, B. (eds). Encyclopaedia of Engineering Geology. Springer International, Cham, 1-15p. 2018.

WISEMAN C. L. S.; ZEREINI F.; PÜTTMANN W. Metal and metalloid accumulation in cultivated urban soils: A medium-term study of trends in Toronto, Canada. Science of the Total Environment, v.538, 564572. 2015. DOI: 10.1016/j.scitotenv.2015.08.085.

ZALASIEWICZ J. The Earth after us: what legacy will humans leave in the rocks? Oxford University Press, Oxford, 251p. 2008. 